Revue bibliographique pour le domaine irano-aryen

\title{
Samra Azarnouche. « Le loup dans l'Iran ancien : entre mythe, réalité et exégèse zoroastrienne »
}

\section{Olivia Ramble}

\section{Q OpenEdition}

1 Journals

\section{Édition électronique}

URL : http://journals.openedition.org/abstractairanica/43737

DOI : 10.4000/abstractairanica.43737

ISBN : 1961-960X

ISSN : 1961-960X

Éditeur :

CNRS (UMR 7528 Mondes iraniens et indiens), Éditions de l'IFRI

Référence électronique

Olivia Ramble, « Samra Azarnouche. "Le loup dans I'Iran ancien : entre mythe, réalité et exégèse zoroastrienne » », Abstracta Iranica [En ligne], Volume 37-38-39 | 2018, document 12, mis en ligne le 30 décembre 2018, consulté le 28 septembre 2020. URL : http://journals.openedition.org/ abstractairanica/43737 ; DOI : https://doi.org/10.4000/abstractairanica.43737

Ce document a été généré automatiquement le 28 septembre 2020.

Tous droits réservés 


\title{
Samra Azarnouche. « Le loup dans l'Iran ancien : entre mythe, réalité et exégèse zoroastrienne »
}

\author{
Olivia Ramble
}

\section{RÉFÉRENCE}

Samra Azarnouche. «Le loup dans l'Iran ancien : entre mythe, réalité et exégèse zoroastrienne ", Anthropology of the Middle East, vol. 11.1, 2016, p. 1-19.

1 Première étude consacrée au loup dans l'Iran ancien. L'A. s'interroge sur le statut de cet animal dans la mythologie animale du zoroastrisme, où il est décrit comme « la bête à abattre " par excellence. Cette image est quelque peu nuancée grâce à des allusions passées jusqu'ici inaperçues - aux liens étroits entre la louve et sa progéniture. Ce contraste se retrouve dans l'iconographie des sceaux magiques sassanides où les deux cas sont figurés. Le second l'est par l'image parfois modifiée de la louve romaine (allaitant tantôt des enfants, tantôt des louveteaux), peut-être à mettre en lien avec la magie périnatale.

\section{AUTEURS}

OLIVIA RAMBLE

Doctorante EPHE, Mondes iranien et indien, Paris 